\title{
The Establishment of Bacteroides ruminicola in a Gnotobiotic Lamb
}

\author{
R. J. LYSONS* \\ School of Veterinary Medicine, Cambridge $\mathrm{CB}_{3}$ oES \\ (Received I2 August I974; revised I9 October 1974) \\ INTRODUCTION
}

Defined but limited floras of 7 to 9 species of rumen bacteria have been established in gnotobiotic lambs, reaching high numbers in the rumen (Lysons et al. 1971; Lysons, 1974). However, these floras contained facultative anaerobes which might have created an anaerobic state in the rumen suitable for establishing other more fastidious and more oxygensensitive rumen bacteria. There appear to have been no attempts to populate a gnotobiotic ruminant with a strictly anaerobic bacterium alone.

Bacteroides ruminicola was chosen because it is commonly isolated from the rumen in high numbers (Hungate, I966) and is an obligate anaerobe.

\section{METHODS}

A single Dorset Poll cross Clun Forest lamb was produced by hysterectomy and reared in gnotobiotic conditions in a flexible film isolator as described by Alexander, Lysons, Elliott \& Wellstead (I973a,b). The lamb was tested periodically to detect contaminant bacteria, fungi or parasites. Samples from the lamb and from the isolator were examined by direct microscopy and by culture. Cultures grown on Sabaraud's agar were incubated aerobically at room temperature, while those on sheep blood agar, nutrient agar and in thioglycollate broth were incubated aerobically and anaerobically at $36^{\circ} \mathrm{C}$ (Elliott, Alexander, Wellstead \& Lysons, 1974).

The lamb was fed sterile cow's milk from birth until 7 weeks of age. At 6 weeks of age a pelleted diet sterilized by gamma radiation was introduced, as described by Lysons ( 1974).

Bacteroides ruminicola strain 46/5 (2) was isolated from the rumen of a sheep which had been fed hay and concentrates using Mann's medium No. 2 (Hobson, 1969). At I I weeks of age the gnotobiotic lamb was dosed orally once with this organism. The inoculum was a IO $\mathrm{ml}$ broth culture incubated for $48 \mathrm{~h}$ at $36^{\circ} \mathrm{C}$ and then stored for $48 \mathrm{~h}$ at $4{ }^{\circ} \mathrm{C}$ while a sample was tested for purity. Although no viable counts were made, it was estimated that the dose was not more than $10^{10}$ organisms.

Rumen samples were taken by stomach tube at intervals after inoculation (Table I). Rumen $\mathrm{pH}$ was determined with a $\mathrm{pH}$ meter (Dyna Cap pH meter; W. G. Pye and Co. Ltd, Cambridge), and viable counts of bacteria made in roll tubes using Mann's medium No. 2.

The lamb was killed with an overdose of pentobarbitone sodium at 17 weeks of age. At death, viable counts were done on the contents of the mid-portion of the small intestine, the caecum and the colon.

\footnotetext{
* Present address: Department of Animal Health, Royal (Dick) School of Veterinary Studies, Edinburgh University Veterinary Field Station, Easter Bush, Roslin, Midlothian.
} 
Table I. Viable counts of $B$. ruminicola and $p H$ of rumen liquor taken 2 to $2.5 \mathrm{~h}$ after feeding

$\begin{array}{ccc}\begin{array}{c}\text { Time from } \\ \text { inoculation } \\ \text { (days) }\end{array} & \begin{array}{c}\text { Rumen } \\ \mathrm{pH}\end{array} & \begin{array}{c}\text { No. of bacteria/ml } \\ \text { rumen liquor }\end{array} \\ -2 & 6 \cdot 6 & 0 \\ 0 & 6 \cdot 6 & 0 \\ \mathrm{I} & 6 \cdot 3 & 2 \times 10^{8} \\ 2 & 4 \cdot 3 & 4 \times 10^{8} \\ 3 & 4 \cdot 7 & 4 \times 10^{8} \\ 4 & 4 \cdot 9 & 1 \times 10^{8} \\ 6 & 5 \cdot 2 & 9 \times 10^{7} \\ 8 & 5 \cdot 1 & 1 \times 10^{8} \\ 15 & 5 \cdot 4 & 7 \times 10^{8} \\ 22 & 6 \cdot 1 & 6 \times 10^{8} \\ 29 & 5 \cdot 9 & 2 \times 10^{8} \\ 36 & 5 \cdot 6 & 1 \times 10^{9} \\ 42 & 6 \cdot 6 & 3 \times 10^{8}\end{array}$

RESULTS

Bacteroides ruminicola established readily in the rumen, reaching a viable count of $2 \times 10^{8}$ bacteria/ml one day after inoculation. As the volume of rumen contents was estimated to be 21 at this stage, it was concluded that the organism multiplied during this period. Viable counts remained at $10^{8}$ to $10^{9}$ bacteria/ml until the animal was killed (Table $\mathrm{I}$ ). At death, the viable counts $/ \mathrm{ml}$ were $4 \times 10^{5}$ in the mid-portion of the small intestine, $5 \times 10^{7}$ in the caecum and $8 \times 10^{7}$ in the colon. The bacterium was not recovered from any part of the body apart from the alimentary tract. No contaminant bacteria or fungi were isolated from skin, rumen or faeces during life or from the extensive microbiological testing at death (Elliott et al. 1974). Bacteroides ruminicola was recovered from the alimentary tract of the gnotobiotic lamb on pre-reduced sheep blood agar plates incubated in a McIntosh and Fildes' jar containing $5 \% \mathrm{CO}_{2}$ and $95 \% \mathrm{H}_{2}$.

The rumen $\mathrm{pH}$ dropped to $\mathrm{pH} 4.3$ in the days following inoculation but thereafter rose again and remained at $\mathrm{pH} 5.4$ to $6 \cdot 6$ until death. (Table I).

At post-mortem examination, the experimental lamb was very similar to lambs kept bacteria-free. The striking features were the small size of the lymph nodes, the thin walls of the rumen and small intestine, and the lack of development of the rumen papillae,

\section{DISCUSSION}

Bacteroides ruminicola established readily in the rumen of a gnotobiotic lamb forming a stable population, without the presence of facultative anaerobes to lower the oxygen tension. The higher viable counts in the caecum and colon than in the small intestine indicates that it multiplied in the intestines as well as the rumen. The viable counts of the organism in the rumen in this lamb were similar to those of the same organism in the rumen of its litter mate, a gnotobiotic lamb which had been inoculated with nine species of rumen bacteria, including a facultative anaerobe (Lysons, 1974).

No measurements were made of the redox potential in the rumen of the gnotobiotic lamb. However, unlike some species of rumen bacteria, $B$. ruminicola grew in a McIntosh and Fildes' jar. 
It would appear that the gnotobiotic lamb is useful for studying certain anaerobic rumen bacteria in vivo.

I acknowledge the helpful advice of T. J. L. Alexander, P. D. Wellstead, P. N. Hobson, S. O. Mann, C. S. Stewart, A. T. Phillipson, and R. E. Hungate, and the excellent technical assistance of L. M. Elliott and M. S. Mitchell. The bacterium was characterized by S. O. Mann of the Rowett Research Institute, Aberdeen. I am grateful for the generous financial assistance of The Wellcome Trust.

\section{REFERENCES}

Alexander, T. J. L., Lysons, R. J., Elliott, L. M. \& Wellstead, P. D. (I973a). Equipment for rearing gnotobiotic lambs. Laboratory Animals. 7, I95-21 7.

Alexander, T. J. L., Lysons, R. J., Elliott, L. M. \& Wellstead, P. D. (I973b). Techniques for rearing gnotobiotic lambs. Laboratory Animals 7, 239-254.

Elliott, L. M., AleXander, T. J. L., Wellstead, P. D. \& Lysons, R. J. (1974). Microbiological monitoring of gnotobiotic lambs. Laboratory Animals 8, $5 \mathrm{I}-59$.

Hobson, P. N. (1969). Rumen bacteria. In Methods in Microbiology, vol. 3B, pp. 133-149. Edited by J. L. Norris and D. W. Ribbons. New York and London: Academic Press.

Hungate, R. E. (1966). The Rumen and its Microbes. New York and London: Academic Press.

Lysons, R. J. (1974). Studies of lambs with a limited microflora. Ph.D. thesis, University of Cambridge.

Lysons, R. J., Alexander, T. J. L., Hobson, P. N., Mann, S. O. \& Stewart, C. S. (197I). Establishment of a limited rumen microflora in gnotobiotic lambs. Research in Veterinary' Science, 12, 486-487. 